\title{
We'll make a man out of you yet: The masculinity of Peter in the book of Acts
}

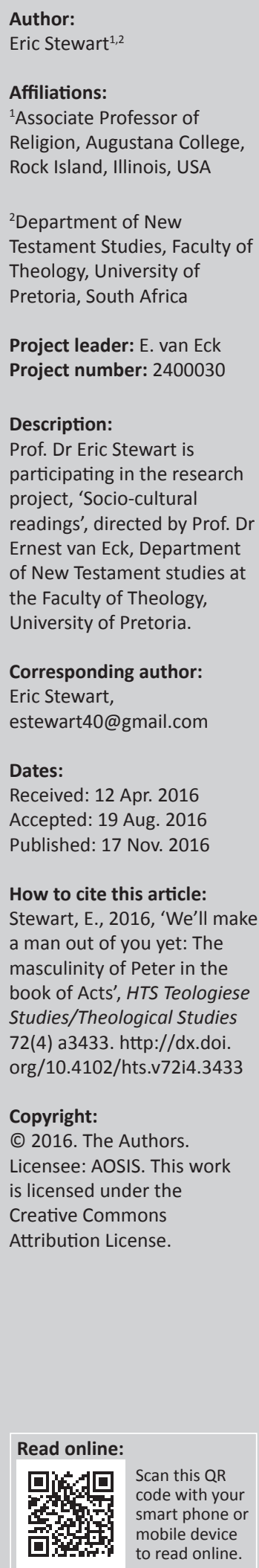

According to scholars of masculinity studies, manhood is won or lost through the performance of gender-based expectations. In any given culture, masculinities exist in hierarchal relationships. The author of the book of Acts shows Peter demonstrating elite masculine performances in the narrative of Acts. Through Peter's self-control, and the lack of self-control on the part of those who oppose him, his persuasive, public speech and his ability to control others in the text, Peter exhibits a masculinity that contradicts early portraits of Peter found in 1 Corinthians and the gospels of Matthew, Mark and John. Peter is not overcome by other people in Acts, and he demonstrates a masculinity that is complicit with the types of masculinities prized by the Romans and often considered out of the reach of foreigners.

\section{Introduction}

As recently as 12 years ago, Moore (2003:1-22), surveying work on masculinity and the New Testament, documented only 11 such studies. Since then, numerous books and articles have emerged as feminist approaches to the New Testament have broadened into gender-critical approaches (Stichele \& Penner 2009:11-43). Masculinity studies, first developed among social scientists in the 1980s (Kimmel 1993:28-35), shed light on numerous elements of the New Testament and its characters (Stewart 2016:91-102). ${ }^{1}$

Masculinity, like femininity, is socially constructed. What it means to be a man in one time and place is different from what it means to be a man in different circumstances. Furthermore, not all males are able to achieve 'real' manhood because of a number of factors. In a cross-cultural study on manhood, Gilmore notes the following:

... a constantly recurring notion that real manhood is different from simple anatomical maleness, that it is not a natural condition that comes about spontaneously through biological maturation but rather is a precarious or artificial state that boys must win against powerful odds is a universal or near universal assumption. (Gilmore 1990:6)

In other words, 'manhood' is not a status that comes automatically with reaching a certain age. Adult males can fail to live up to the status of 'real men' in a society because of hierarchies of masculinity. 'Hegemonic' masculinity is the dominant form of masculinity in any given culture (Connell \& Messerschmidt 2005:832-33; Levy 2007:253-55). Hegemonic masculinity refers generally to at least three things: '(1) a position in the system of gender relations; (2) the system itself; and (3) the current ideology that serves to reproduce masculine domination' (Levy 2007:254). Hegemonic masculinity then can refer to the male(s) at the top of the hierarchical system, the hierarchical system itself that ranks some men ahead of others, or the particular constellation of masculine features that are valued at a particular time in a particular place. This type of masculinity is accompanied by at least three others: complicit, subordinate and marginalised masculinities. Complicit masculinities are enacted by those men 'who received the benefits of patriarchy without enacting a strong version of masculine dominance' (Connell \& Messerschmidt 2005:832). Men enacting complicit masculinities include those whose characteristics make them resemble those enacting hegemonic masculinity in some key aspects (for instance, in the US context, white, affluent, young, able-bodied, heterosexual, etc.), but who do not stand at the top of the masculine hierarchy. Subordinate masculinities are practiced by those who are able to practice hegemonic masculinity but for some reason do not do so. These men still benefit from the system even though they are not at its apex. Such men might reject dominance or violence as a way to achieve their aims even though their society values these as 'masculine' traits. Men who exhibit marginalised masculinities often have a status that prevents them from attempting to achieve hegemonic masculinity, such as a minority ethnic status and a mental or physical disability (Levy 2007:254).

1.For a recent survey of studies approaching the New Testament and early Christianity through masculinity studies. 
It is important to note that only a small percentage of men might be able to practice hegemonic masculinity; however, hegemonic masculinity as a hierarchical system still exerts influence over other types of masculinity, sometimes through violent force, other times 'through culture, institutions, and persuasion', enforced ritual and 'pageantry', and yet other times through social activity such as verbal censure and criminalisation of certain activities (Connell \& Messerschmidt 2005:832).

These various types of masculinities call attention to the fact that masculinity is always something performed or 'done' (West \& Zimmerman 1987:125-51). 'Doing gender' means 'a person engaged in virtually any activity may be held accountable for performance of that activity as a woman or man, and their incumbency in one or the other sex category can be used to legitimate or discredit their activities' (West \& Zimmerman 1987:136). Doing gender does not necessarily mean only living or failing to live up to the 'normative conceptions of femininity or masculinity' but to do so 'at the risk of gender assessment' (West \& Zimmerman 1987:136). Such gender assessment relates to the notion that to be a 'man' is never a completely fixed status. Men can be judged 'manly' in one context and 'unmanly' in another. All men risk being judged unmanly when undertaking any activity in which they might be judged according to standards of masculinity.

\section{Doing masculinity in the Roman world}

Performing masculinity in the Greek and Roman worlds meant displaying characteristics associated with 'maleness'. While masculinity was never only one fixed characteristic, Romans and Greeks shared a cluster of characteristics related to manhood. To be a man meant to avoid things that were the opposite of manliness (Kuefler 2001:19-36). Roman men expressed masculinity in a variety of ways: through physical domination of and violence towards others, through cultivation of certain virtues, through oratorical performance and rhetorical dominance of others, and through various displays of status. Early Christians interacted with Roman claims to masculinity in a variety of ways. One major tenet of Roman masculinity was the impenetrability of the male body. Elite Roman males penetrated other bodies, both sexually and through other types of bodily acts (Walters 1997:29-43; Williams 2010:137-176), such as beatings (Glancy 2004:107-113).

McDonnell argues that aggressiveness in battle and bravery in the face of pain and death marked Roman manliness, especially in the pre-Classical period (2006:12-71). Bravery is a key characteristic of manliness, and those who do not display bravery in the face of hardship are less than true men. Indeed, the Greek word for courage, $\alpha \nu \delta \rho \varepsilon i \alpha$, is derived from the Greek word for man, $\dot{\alpha} v \eta \dot{\varphi} \rho$ or $\dot{\alpha} v \delta \rho o ́ s$. Beyond this type of courage, power also is a key feature of manhood. The paterfamilias, the oldest living male member in a household, exercised potestas ('dominion') over the other members of the household: wives, sons, grandchildren, great-grandchildren and slaves (McDonnell 2006:168-172). The paterfamilias exercised wide-ranging authority, including being the only member of a household legally to own property, the authority to arrange and annul marriages among his children, the ability to sell children and grandchildren into slavery and the right over their very lives (McDonnell 2006:173).

In addition to dominance over family members, boys were socialised to compete with and to dominate their peers (Bartchy 1999:68-78; Bloomer 1997:57-78). There were several elements of the Roman educational system designed to train boys to be dominant men. Fathers, at least among the elite, taught their sons to throw javelins, fight in armour and ride horses (McDonnell 2006:181-195). Roman citizens also served a year of military apprenticeship after they donned the toga virilis ('toga of manhood'). Bloomer shows how the school exercises of declamation and the corresponding adoption of the personae of subordinate members of the household taught boys the skills necessary for life both as patresfamilias and public figures. These school exercises taught the boys how to exercise authority over others in every context. In addition to being useful in school, such exercises in rhetoric taught boys how to perform their speeches in front of others in ways that would be deemed manly (Gleason 1995:82-84; Gunderson 2000:29-57). This type of dominance in public speech fit into the public nature of the exchange of honour through the practice of challenge and riposte (Rohrbaugh 2010:113-115). Public speeches were occasions for honour to be earned through persuasive speech that won over the audience. Failure to win the audience resulted in shame for the speaker (Barton 2001:136-142).

Finally, among the most quintessential markers of Roman masculinity was the idea of self-control or self-mastery. Selfcontrol is one of the four cardinal virtues of Greek and Roman philosophical tradition. While the four, prudence (Greek:

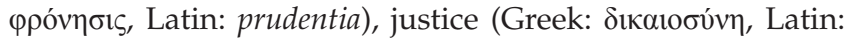

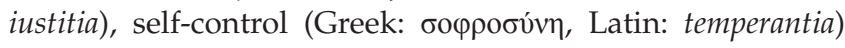
and courage (Greek: $\dot{\alpha} v \delta \rho \varepsilon i ́ \alpha$, Latin: fortitudo), include more than self-control, self-control came to symbolise the four as a group. A related virtue, غ่ $\gamma \kappa \rho \alpha ́ \tau \varepsilon ı \alpha$ (agonistic self-mastery), 'received a distinctly masculine inflection in classical Greek literature; it was a manly virtue, a virile virtue' (Moore \& Anderson 1998:258). Men who displayed self-mastery, the ability to ward off all things 'womanish', were deemed real men (Williams 2010:151-156). 'Mastery - of others and/or of oneself - is the definitive masculine trait in most of the Greek and Latin literary and philosophical texts that survive from antiquity' (Moore \& Anderson 1998:250).

Craig Williams sums up what it means to 'do gender' in terms of Roman manliness:

\footnotetext{
A man might lose his grip on masculine control in various ways: by indulging in an excessive focus on his appearance or making himself look like a woman, by seeking to be dominated or even penetrated by his sexual partners, by subjugating himself to others for the sake of pleasuring or entertaining them, or by yielding to his own passions, desires, and fears. Masculinity was not fundamentally a matter of sexual practice; it was a matter of control. (Williams 2010:155)
} 


\section{Gender and Acts}

Several studies have already undertaken to examine issues of gender in Luke-Acts. Among these studies, relatively a few examine masculinity in particular. ${ }^{2}$ These studies point to a number of features that are significant for our understanding of Acts in particular. Penner and Stichele (2004:193-198) argue that Acts presents violence as a distinguishing characteristic between insiders and outsiders. Insiders to the Jesus movement have violence done to them, while outsiders are the ones doing the violence. Reading a bit more carefully, however, one can see that violence also happens to those who oppose the movement, both from the inside and the outside. Penner and Stichele (2004:193-198) discuss the cases of Ananias and Sapphira (Ac. 5:1-11), Herod's demise (Ac. 12:20-23) as well as that of Elymas (Ac. 13:11). The death of Judas could also be added to these examples (Ac. 1:18-19). Beyond the physical violence done to outsiders (and insiders turned outsiders), there is also the 'violence' of 'verbal aggression in directly condemning their opponents' (Penner \& Stichele 2004:197). As Acts describes members of the Jesus movement as subjects of others' violence, the overall impression left by Acts is 'a subtle yet powerful insider view of violence, that is, when "we" do it, it is "justice"; when "they" do it, it is "violence"' (Penner \& Stichele 2004:198).

Apart from Saul's activity in Acts before his change of allegiance to the risen Christ, Jesus' followers do not do physical violence to others in the book of Acts. The early followers of Jesus were not in a position successfully to do violence to others in any kind of sustained way. This fact is not true either for the risen Jesus (Ac. 9) or for God (Ac. 5:1-10). Furthermore, Peter is involved in a scene of violence which causes the death of two people. It is clear from the text of Acts that Peter himself does not kill Ananias and Sapphira, but he serves a God powerful enough to do so when they lie to Peter. Considering how important dominance over and violence towards others are to defining Roman manhood, that the apostles prevail in speech against their opponents, and that they represent a supernatural agent who has the last word regarding violence in the text, Acts constructs a situation in which to be aligned with the ultimate masculine power (God) provides access to masculine display.

D'Angelo points out how Acts circumscribes roles for women through its borrowing of imperial masculinities (D'Angelo 2002:45-69, 2003:265-295). Luke-Acts presents its leading characters as including 'Roman citizens who are of the highest calibre, who practise the financial probity and family values that the imperial order preaches with dubious effect' (D'Angelo 2002:47). D'Angelo reads this description of men in Acts as a strategic

defense against the charge that Christians preach un-Roman activities, mores $(\grave{\eta} \theta \eta)$ not permitted to Romans (Ac.16:20-21). On the contrary, the Christians show themselves to be exempla of the very practices the imperial order seeks (less than successfully) to foster. (D'Angelo 2002:68)

2.Although this list is not exclusive, a few studies that do examine Acts through the lens of masculinity are D’Angelo (2002, 2003), Flessen (2011), Penner and Stichele $(2004,2007)$ and Wilson $(2015 a, 2015 b)$.
The main function of men in the world of Acts, according to D'Angelo, is presiding over their households, demonstrating the 'family values' first put into place by Augustus and later reinscribed by Trajan and Pliny (D'Angelo 2003:284-293). For D'Angelo, Acts presents its leading men as elite figures or, at least, as figures who live according to the professed values of imperial masculinity. In so doing, these figures enact a complicit masculinity based on the value system of Roman masculinity.

Wilson takes an opposing view with respect to the masculinity of the leading men of Acts. Despite noting that the majority of studies involving masculinity in Acts treat the leading figures as heroic exemplars of masculine virtues, Wilson argues that the author of Acts:

provides a reconfigured - or refigured - masculinity that is often at odds with his surrounding culture. Luke's male characters at times appear manly, but more often than not they look unmanly in comparison to elite masculine norms. (Wilson 2015b:21)

Rather than hegemonic masculinity, Wilson prefers the phrase 'elite masculine norms' (2015b:23) to indicate that there was no single hegemonic masculinity in the Roman Empire. Wilson's study examines both 'marginal' masculine characters (Zechariah and the Ethiopian eunuch) and 'major' characters (Paul and Jesus) and concludes that an elite male would not have seen the men of Acts as elite men themselves because of their status, ethnic identity, religious affiliation and lack of political or military power (2015b:248-254). While serious attention must be paid to these critiques, especially as they relate to the issue of intersectionality, Peter still maintains an elite position relative to the other men whom he encounters in the text, men who are specifically 'othered' in relation to Peter.

\section{Peter in Acts}

Like all other men before and after, Peter's status as a man was subject to contestation. Paul in his letter to the Galatians and the authors of the gospels Mark, Matthew and John all insinuate in various ways that Peter does not meet the measure of a man. Luke-Acts, on the other hand, and particularly Acts, produces a Peter who demonstrates the full measure of manhood. Peter's characterisation in Acts is somewhat surprising for a number of reasons. Firstly, Peter is the clear leader among the 12 disciples. The gospels often present Peter as falling short of ideal following of Jesus (Stewart 2012:30-51). In Acts, his ability to control other people is an indicator of his masculine performance. Secondly, Peter is presented as speaking boldly in public and without fear. This differs from Paul's discussion of Peter in Galatians 1-2, where Paul attributes Peter's change of behaviour at Antioch to fear (Stewart 2011) and Mark and Matthew attribute Peter's denial of Jesus to fear. Peter's ability to persuade numerous people to join the Jesus movement is a telling indicator of his public performance of masculinity. More significantly, people who oppose Peter are characterised by high emotion and a lack of self-control, and also by fear. Thirdly, Peter's social status is raised at the same time that 
the author of Acts indicates awareness of the lack of public status Peter possesses (Ac. 4:13). Finally, perhaps most surprising to anyone familiar with Paul's letters, Peter is described in Acts as the follower of Jesus through whom the 'nations' (Greek: $: \theta v \eta)$ would join the Jesus movement. Peter's proclamation in Acts 15:7 is related to the vision and subsequent visit with Cornelius (Ac. 10:9-48). Peter's bold public speech, his lack of fear and his social status in the book of Acts all diverge in meaningful ways from earlier characterisations of Peter (Stewart 2012:16-51). The new ways in which Peter is characterised relate to common concerns about masculinity in the Graeco-Roman world. Peter's masculinity is enhanced significantly through the portrayal in Acts. Peter does not represent the masculinity of a Roman emperor or soldier in that he does not dominate other people directly by means of physical violence. He does, however, demonstrate masculinity in two key ways: oratorical performance and mastery over self and others, the latter of which allows him to dominate other people (Williams 2010:151-156).

\section{Self-control}

The literary preface to the Acts of the Apostles makes clear that the group of apostles whom Jesus chose were commanded

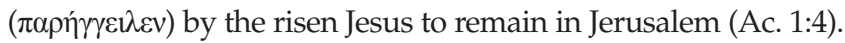
That Peter is part of this group of selected apostles is made clear throughout the narrative of the book of Acts. We should already note a key feature concerning masculinity. The risen Jesus is more powerful than Peter and the other apostles, and he rightly, therefore, is able to command them and expect obedience. In other words, like most men in ancient Judea, Peter is not at the top of the rung of the masculine hierarchy. Although he does have ability to control the actions of both human and non-human agents, ultimately he is under the authority of a still more significant power.

Given the emphasis on self-control in portrayals of masculinity in the Greek and Roman contexts, it might be argued that Jesus' ability to control Peter's actions makes Peter unmanly. This reading of the text would certainly fit with Wilson's understanding of Paul in Acts 9. There Paul is overcome by a heavenly power far superior to himself, and shows several significant signs of lack of self-control: he falls to the ground while his companions do not; he is blinded; his companions must lead him away by the hand because he cannot see; and he is dependent upon Ananias to restore his sight (Wilson 2015a:243-248). Peter, however, is never depicted as overcome in the same way by either Jesus or the Spirit in Acts. The closest Peter comes to being overcome is in Acts 10 when he is instructed in trance to 'kill and eat' (Ac. 10:13). Furthermore, being subject to higher powers is part of piety, a quality which Peter possesses throughout the text (Conway 2008:45-47; D’Angelo 2007).

In other situations in Acts, Peter is clearly in control. Peter is first introduced by name in Acts 1:13. He is listed first in a list of names of the apostles, and they and others who are not apostles met together in the upper room (1:12-14). Even within the synoptic gospels, Peter is always listed first among the named disciples when they are named (Stewart 2012:51).

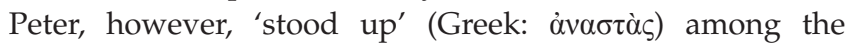
siblings in order to determine a replacement for Judas among the apostles (Acts 1:15-22). Peter's speech among the siblings in the upper room foreshadows the longer and much more public speeches that he will make on Pentecost (Ac. 2:14-36 and 3:11-26). Peter's control of the situation in the upper room is derived from his portrayal in Acts as one who is in control of himself.

Acts does not use the language of the four cardinal virtues in reference to Peter. Although we have some indication that the author is aware of this language (see Ac. 24:25 where ह่ $\gamma \kappa \rho \alpha \tau \varepsilon i ́ \alpha$

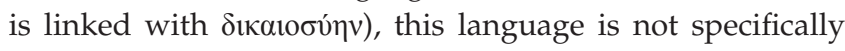
used with regard to Peter. Yet Peter still demonstrates qualities associated with manly performance of the virtues. Perhaps nothing indicates Peter's manliness in the book of Acts more than his lack of fear and his control over his emotions. While in many cases Peter is not credited for these masculine indicators directly, the fact that others demonstrate fear and excessive emotion in his presence with some frequency serves all the more to highlight Peter's lack of emotion. ${ }^{3}$ Paul characterised Peter's changed behaviour as motivated by fear in Galatians 2:12 (Stewart 2011). Both Mark and Matthew claim that Peter operated out of fear (Mk. 9:6, 9:32, 10:32; Mt. 14:30). In Luke-Acts, Peter's behaviour is not motivated by fear, although his behaviour causes others to fear. In response to Peter's first speech which drew 3000 new followers to the movement, 'fear in every soul' came about (2:43). As soon as Peter finished speaking to Ananias, Ananias died and 'great fear came to everyone who heard about it' (5:5). Again, after the death of Sapphira, the 'whole church' was in 'great fear' (5:11).

This pattern influences the way in which the author describes the authorities who oppose Peter. When we first meet them,

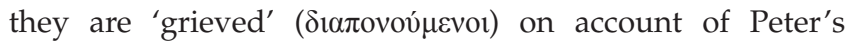
speaking to the crowd about the resurrection of Jesus (Ac. $4: 1-2)$. Peter's speech before these assembled 'rulers' and 'elders' explicates that Jesus is the only name by which salvation might be achieved (4:8-12). Peter is distinguished at the beginning of his speech as 'being filled with the Holy Spirit' (4:8). His spirit-filled demeanour should be read in contrast to those who would judge him. After his speech, they order Peter (and John, who to this point has not had a speaking role) to cease and desist from preaching about Jesus. Peter and John answer that they are unable to do so (4:19). Even though the 'rulers' and 'elders' wish to punish them, it is impossible for them to do so 'on account of the

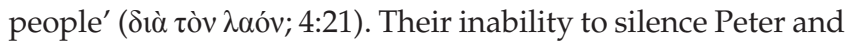
John, taken together with the fear of the prefect and officers in 5:26, is an indication that the opponents of Peter are not manly enough to perform the duties for which they are responsible.

3.1 have argued elsewhere that Luke and Acts both work towards softening the negative features of Peter's characterisation present in other New Testament texts (Stewart 2012:46-50, 52-66). 
To make matters even worse for those who oppose Peter,

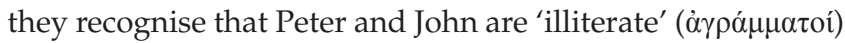

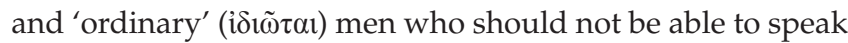
with the 'boldness' ( $\pi \alpha \rho \rho \eta \sigma i \alpha v)$ that they demonstrate (4:13). In other words, these two men lack the requisite training in public speaking to best their (supposed) superiors, but that is just what they do in this encounter. The possession of the Holy Spirit enables Peter's oration to be persuasive enough to make the crowd interceding on his behalf a real threat. Their bold speech $(\pi \alpha \rho \rho \eta \sigma i \alpha)$ is characteristic of the apostles (A. 2:29, 4:13, 29, 31). Such bold speech is also characteristic of philosophers who stand up to tyrants. By introducing this word ( $\pi \alpha \rho \rho \eta \sigma i ́ \alpha)$ here in reference to the 'rulers' and 'elders', the author of Acts likely means to draw upon this tradition (Dupertuis 2013:156-158). This type of opposition often takes the form of fidelity to some larger concern. In this case, Peter tells them that 'it is necessary to obey God more than humans' (4:29).

In what is perhaps the most interesting case, when the prefect and the officers come to arrest the apostles who have been freed from prison, they did so 'without violence' (ov̉ $\mu \varepsilon \tau \grave{\alpha}$ ßías)

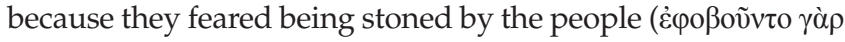

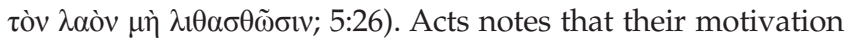
for arresting the men in the first place was their being 'full of

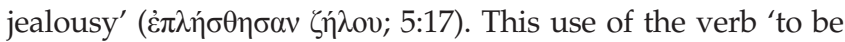
filled' is almost surely meant to be contrasted with Peter's being 'filled' with the Holy Spirit. The very men who ought to be able to control the people are unable to do so. Penner and Stichele (2009) note that in Acts there is no violence in Athens, while there is violence along the 'edges' of empire in Asia Minor and Jerusalem. The Romans, who are omnipresent in some ways throughout the text, are unable to control these marginal spaces (Penner \& Stichele 2004:198-209). The threat of mob violence here is related to this geographic pattern by which the author of Acts suggests that Judea is on the edge of the empire and, as such, constitutes marginal, violent space that is not easily controlled by those in authority. Such a perspective of 'otherness' regarding Judeans (Wilson 2015b:19-21; see also Cobb 2012:80-86) makes Peter's selfcontrol much more significant in contrast. Once the escapee apostles have been recovered, they refuse to discontinue their preaching about Jesus (4:27-32). This refusal results in the high

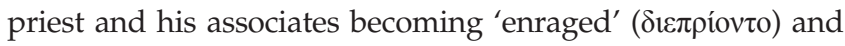

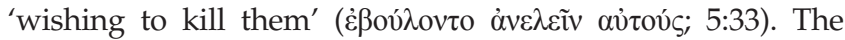
overwhelming nature of the emotions experienced by these leaders is clearly meant to mark them as unmanly, lacking selfcontrol, in clear contrast to the manliness demonstrated by Peter and the other apostles. ${ }^{4}$

The opponents of Peter, driven by fear, grievance, jealousy and by an unyielding desire to restrain the public speech of the apostles, are unable to control him. The apostles refuse to stop proclaiming Jesus, and the authorities, inviting them back in after they had sent the apostles out, 'scourge' them (5:40) before letting them go. Being beaten might mark the apostles as unmanly. It can be taken as a sign that they are unable to prevent their bodies from being penetrated (Glancy 2004:108-109), while at the same time those who whipped other men without proper cause could also be seen as unmanly and those who endured such whipping without complaint could be seen as bearing pain in a manly fashion (Glancy 2004:110-118). In this case, however, Acts immediately moves to mitigate the damage to Peter's masculinity, both in terms of tying the 'dishonour' experienced by the disciples to the 'worthiness of the name' (5:41) and insisting that 'every day in the temple and in each household they did not stop teaching and proclaiming the Christ, Jesus' (5:42). The beating serves only to link them further to Christ and the proclamation of Christ. They do not stop doing the very thing they were ordered to do by the temple authorities. The threat to Peter's manliness that results from the beating is dismissed by demonstrating that Peter neither stopped his activity nor became afraid.

\section{Public speech}

Clines has noted that persuasive public speech is a characteristic male marker in ancient Israel as well as within the early Jesus groups (Clines 2003:186-188). Peter's first major public speech comes during Pentecost. When 'others' jeered at the disciples for speaking in tongues (Ac. 2:13),

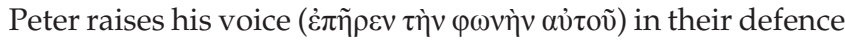
(2:14). Beginning his speech by appealing to the 'men' (öv $\delta \rho \varepsilon \varsigma)$ of Judea and all those living in Jerusalem (2:14), Peter recounts the prophecy of Joel to explain why Jesus' followers are speaking in tongues $(2: 15-21)$. In the next section of his speech, he recounts the story of Jesus' death and resurrection and David's attesting to it (2:22-36). From the perspective of masculinity, what is important to note is that the speech is persuasive (Penner 2003:97-98). The reaction of the crowd is to ask what they should do in light of Peter's story (2:37). Around 3000 persons were baptised and 'they attended constantly to the apostles' teaching and to fellowship, by breaking of bread and by prayers' (Ac. 2:42). Peter (together with his fellow apostles) controls the actions of this crowd of people through Peter's persuasive speech.

Peter's second major public speech in Acts (3:12-26) casts the 'men, Israelites' (3:12) in the role of those who asked for a 'man, a murderer' (ö $\delta \delta \rho \alpha$ $\varphi$ ové $\alpha$ ) to be released rather than Jesus (Ac. 3:14). This accusation, even though Peter acknowledges that both these men and their rulers 'did this act in ignorance' (3:17), shows these men to be unjust, lacking virtue. The accusation is followed by the arrest of Peter and John by the priests, the prefect of the temple, and the Sadducees. Peter's speech convinces 5000 more men to join the movement. The further outcome of Peter's speech and the healing which preceded it, although they resulted in arrest, is narrated by those who arrest Peter in 4:21-22: 'all gave glory to God over what had happened'. The community came back together (4:23-31) and shared all of their belongings (4:32-37) in the midst of the apostles acting with 'power' (4:33). This power is that which was promised by Jesus when the Holy Spirit came upon them (Acts 1:8). Power here is a key marker of masculine identity. While 'all' of them, 
presumably including women, received 'great grace' (4:33), 'power' is restricted to the male apostles.

Peter's speech is not only convincing to outsiders. In a key moment in Acts, 'those of the circumcision' contended with Peter concerning his eating with 'uncircumcised men' (11:2-3). Peter, relating the account of his trance vision, 'silenced' (íví $\alpha \sigma \alpha \nu$ ) these contenders, causing them to give glory to God (11:18). In his final scene in Acts, Peter again 'stood up' ( $\dot{\alpha} v \alpha \sigma \tau \grave{\alpha} \varsigma$ ) to convince the Jerusalem council to admit the

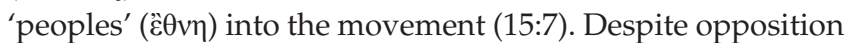
to allowing them to enter the movement without being circumcised, Peter's position prevailed when James was convinced by it (15:13-21). Peter's ability to prevail over his opponents in public speaking, whether they are insiders or outsiders to the movement, signals his manliness.

\section{Control over others}

Peter exhibits control over others in a number of ways throughout Acts. In addition to being the leading figure among the apostles and others gathered in the upper room, Peter heals a paralytic (3:1-10). Peter's healing is not limited to this one instance. In fact, Peter's reputation as a healer becomes so great that even his shadow is capable of healing (5:12-16). His voice is enough to announce that Jesus heals Aeneas (9:32-35), and he commands Tabitha to rise after she had died (9:40). Peter's control over the bodies of others, obviously granted from Jesus (3:6, 9:34), allows him to perform healings. At the same time, Peter controls these abilities enough to be able to refuse to sell them to Simon (8:14-24). While the spirit comes upon others throughout the text (notably, Cornelius and his household in 10:44), Peter brokers the spirit in the text.

Peter controls others through more than just his healings. As noted above, Peter sets the qualifications for replacing Judas among the 12 apostles (1:20-22). Peter controls the situation with Ananias and Sapphira, accusing them of lying and 'presiding' over their deaths (5:1-11). In perhaps the most compelling scene of Peter's control over others in Acts, Peter also controls Cornelius and his household when he 'ordered' ( $\pi \rho \circ \sigma \varepsilon \dot{\tau} \alpha \xi \varepsilon v)$ that they be baptised in Jesus Christ's name (10:48). Peter's speech is once again effective, causing the Spirit to come upon the members of Cornelius' household. Peter also insists, despite Cornelius' 'falling upon his feet' and 'doing obeisance' to him (10:25), that Cornelius should treat him as a mortal and not give to Peter honour owed to God. Peter has the ability to 'order' a centurion, something that ought to be available only to a high-ranking Roman official, because of the superiority of the male authority (God) whom he serves.

\section{Conclusion}

Peter does not display hegemonic masculinity in Roman terms or in terms of the emerging Jesus movement. He does, however, demonstrate a complicit masculinity. He participates in the violence done by God to those who stand against God.
He upholds Roman hegemonic values of masculinity through his control of self, his public speech and his domination of others. Although he is a Judean, an ethnicity that should mark him as not quintessentially masculine from the Roman perspective, the author contrasts him with other Judeans in that he is not marked by excessive passion, fear or an inability to control his emotions. The book of Acts provides us a portrait of Peter in which he demonstrates self-mastery and control of others. He is a public figure who speaks boldly throughout the scenes in which he is involved in the narrative, and he has the ability to silence his critics, both internal (11:18) and external (4:14). His rhetoric is particularly effective, drawing once 3000 and another time 5000 new members to the movement, in spite of his status as 'uneducated' and 'ordinary'. He leads the group of Jesus followers, 'standing up' both in the beginning of the text and during the Jerusalem council. He controls people through his ability to heal and through his ability to announce judgement. He is 'filled with the spirit' in contrast to his opponents who are 'filled with jealousy'. He also controls the influx of the peoples ( $\theta 0 v \eta$ ) into the Jesus movement. Peter is quintessentially masculine in this text. Although he is arrested twice, no great harm befalls him. Even when he is scourged, the scourging does nothing to dissuade him from his task. He is given 'power' by his heavenly patron, and he does not falter from his proclamation. He is complicit in the masculinity of God and the heavenly Jesus, even as he upholds the values of Roman manliness through domination, piety and persuasion.

\section{Acknowledgements}

It is my great privilege to contribute to this special issue of HTS Theological Studies/Teologiese Studies celebrating the Centenary Anniversary of the Faculty of Theology at the University of Pretoria. The research produced by the Faculty of Theology, together with the hospitality they have shown in hosting international scholars, is a cause for celebration both in South Africa and throughout the world. May they continue to provide a model for an engaged scholarship for those in their homeland and for those around the world.

\section{Competing interests}

The author declares that he has no financial or personal relationships which may have inappropriately influenced him in writing this article.

\section{References}

Bartchy, S.S., 1999, 'Undermining ancient patriarchy: The Apostle Paul's vision of a society of siblings', Biblical Theology Bulletin 29(2), 68-78.

Barton, C.A., 2001, Roman honor: The fire in the bones, University of California Press, Berkeley, CA.

Bloomer, W.M., 1997, 'Schooling in persona: Imagination and subordination in Roman education', Classical Antiquity 16(1), 57-78. http://dx.doi.org/10.2307/25011054

Clines, D.J.A., 2003, 'Paul, the invisible man', in J.C. Anderson \& S.D. Moore (eds.), New Testament masculinities, pp. 181-192, Semeia Studies 45, Society of Biblical Literature (SBL), Atlanta, GA.

Cobb, L.S., 2012, Dying to be men: Gender and language in early Christian martyr texts, Columbia University Press, New York. 
Connell, R.W. \& Messerschmidt, J.W., 2005, 'Hegemonic masculinity: Rethinking the concept', Gender and Society 19(6), 829-859. http://dx.doi.org/10.1177/ 0891243205278639

Conway, C., 2008, Behold the man: Jesus and Greco-Roman masculinity, Oxford University Press, Oxford.

D'Angelo, M.R., 2002, 'The ANHP question in Luke-Acts: Imperial masculinity and the deployment of women in the early second century', in A.J. Levine \& M. Blickenstaff (eds.), A feminist companion to Luke, pp. 44-69, Sheffield Academic Press, London.

D'Angelo, M.R., 2003, “"Knowing how to preside over his own household": Imperia masculinity and Christian asceticism in the Pastorals, Hermas, and Luke-Acts', in J.C. Anderson \& S.D. Moore (eds.), New Testament masculinities, pp. 265-295, Semeia Studies 45, SBL, Atlanta, GA.

D'Angelo, M.R., 2007, 'Gender and geopolitics in the work of Philo of Alexandria: Jewish piety and imperial family values', in T. Penner \& C.V. Stichele (eds.), Mapping gender in ancient religious discourses, pp. 63-88. Biblical Interpretation 84 , Brill, Leiden.

Dupertuis, R.R., 2013, 'Bold speech, opposition, and philosophical imagery in the Acts of the Apostles', in R.R. Dupertuis \& T. Penner (eds.), Engaging early Christian history: Reading Acts in the second century, pp. 153-168, Acumen, Durham, NC.

Flessen, B.J., 2011, An exemplary man: Cornelius and characterisation in Acts 10, Wipf \& Stock, Eugene, OR.

Gilmore, D.G., 1990, Manhood in the making: Cultural concepts of masculinity, Yale University Press, New Haven, CT.

Glancy, J.A., 2004, 'Boasting of beatings (2 Corinthians 11:23-25)', Journal of Biblical Literature 123(1), 99-135. http://dx.doi.org/10.2307/3268552

Gleason, M.W., 1995, Making men: Sophists and self-presentation in ancient Rome, Princeton University Press, Princeton, NJ.

Gunderson, E., 2000, Staging men: The rhetoric of performance in the Roman world The body, in theory, University of Michigan Press, Ann Arbor, MI.

Kimmel, M.J., 1993, 'Invisible masculinity', Society 30(6), 28-35. http://dx.doi. org/10.1007/BF02700272

Kuefler, M., 2001, The manly eunuch, University of Chicago Press, Chicago, IL.

Levy, D.P., 2007, 'Hegemonic masculinity', in M. Flood, J.K. Gardiner, B. Pease \& K. Pringle (eds.), International encyclopedia of men and masculinities, pp. 253-255, Routledge, London.

McDonnell, M., 2006, Roman manliness: Virtus and the Roman Republic, Cambridge University Press, Cambridge.
Moore, S.D., 2003, “'O man who art thou ...?” Masculinity studies and New Testament studies', in J.C. Anderson \& S.D. Moore (eds.), New Testament masculinities, pp. 1-22, Semeia Studies 45, SBL, Atlanta, GA.

Moore, S.D. \& Anderson, J.C., 1998, 'Taking it like a man: Masculinity in 4 Maccabees' Journal of Biblical Literature 117(2), 249-273. https://dx.doi.org/10.2307/ 3266982

Penner, T., 2003, 'Civilising discourse: Acts, declamation, and the rhetoric of the Polis', in T. Penner \& C.V. Stichele (eds.), Contextualising Acts: Lukan narrative and GrecoRoman discourse, vol. 20, pp. 65-104, SBL Symposium Series, SBL, Atlanta, GA.

Penner, T. \& Stichele, C.V., 2004, 'Gendering violence: Patterns of power and constructs of masculinity in the Acts of the Apostles', in A.J. Levine \& M. Blickenstaff (eds.), $A$ feminist companion to Acts, pp. 193-209, T \& T Clark, London.

Penner, T., \& Stichele, C.V., 2007, 'Script(ur)ing gender in acts: The past and present power of imperium', in T.C. Penner \& C.V. Stichele (eds.), Mapping gender in ancient religious discourses, pp. 231-66. Biblical Interpretation 84. Brill, Leiden.

Rohrbaugh, R.L., 2010, 'Honor: Core value in the biblical world', in D. Neufeld \& R.E. DeMaris (eds.), Understanding the social world of the New Testament, pp. 109-125, Routledge, London.

Stewart, E.C., 2011, 'I'm okay, you're not okay: Constancy of character and Paul's understanding of change in his own and Peter's behaviour', HTS Teologiese Studies/Theological Studies 67(3). https://dx.doi.org/10.4102/hts.v67i3.1002

Stewart, E.C., 2012, Peter: First-generation member of the Jesus movement, Liturgical Press, Collegeville, MN.

Stewart, E.C., 2016, 'BTB reader's guide: Masculinity in the New Testament', Biblical Theology Bulletin 46(2), 91-102. http://dx.doi.org/10.1177/0146107916639211

Stichele, C.V. \& Penner, T.C., 2009, Contextualising gender in early Christian discourse: Thinking beyond Thecla, T\&T Clark, London.

Walters, J., 1997, 'Invading the Roman body: Manliness and impenetrability in Roman thought', in J.P. Hallett \& M.B. Skinner (eds.), Roman sexualities, pp. 29-43, Princeton University Press, Princeton, NJ.

West, C. \& Zimmerman, D.H. 1987, 'Doing gender', Gender and Society 1(2), 125-151. http://dx.doi.org/10.1177/0891243287001002002

Williams, C.A., 2010, Roman homosexuality, 2nd edn., Oxford University Press, Oxford.

Wilson, B.E., 2015a, 'Destabilising masculinity: Paul in the Book of Acts and beyond', Journal of the Bible and Its Reception 2(2), 241-261. http://dx.doi.org/10.1515/ jbr-2015-0013

Wilson, B.E., 2015b, Unmanly men: Refigurations of masculinity in Luke-Acts, Oxford University Press, Oxford. http://dx.doi.org/10.1093/acprof:oso/97801993250
09.001 .0001 